\title{
Assessment of food security in the regions of the Arctic zone of the Russian Federation
}

\author{
Aleksey Pestryakov, Ekaterina Reutova, Nadezhda Sbrodova, and Alisa Titovets \\ Ural State Univercity of Economics, 620144 Yekaterinburg, Russia
}

\begin{abstract}
Food security issues are among the priority areas for the development of the regions of the Arctic zone, both on the territory of the Russian Federation and abroad. The sustainable development of the territory largely depends on the satisfaction of the basic needs of the population. For a detailed and comprehensive assessment of the situation on this issue, a qualitative methodology is required, which will most objectively reflect the state of food security in the regions of the Arctic zone. The study analyzes the existing methods of assessing food security, justifies their main advantages and disadvantages. The authors propose their own methodology for assessing the food security of the regions of the Arctic zone, which uses the most common indicators used in previous methods, and is also based on the main socially significant features of the regions of the Arctic zone (small population, limited opportunities for food production).
\end{abstract}

\section{Introduction}

The issue of food security of territories remains relevant for any country and any region throughout their existence. Within the framework of the concept of sustainable development, it refers to the basic whole of sustainable development and the primary needs of the population. This is especially true for territories for which agriculture is not a branch of specialization, such as the regions of the Arctic zone.

Initially, the "Arctic or Arctic Region, or Arctic Zone" is a part of the earth's spheroid, the center of which is the North Pole [1]. In the world community, there is no single opinion on the borders of the Arctic and no single term for defining the Arctic (High North, Far North). The countries that own such regions use the concept of "Arctic region" in the most important strategic documents [2-10]. The global significance of the Arctic regions, according to experts, lies in the fact that they are promising places for capital investment from the standpoint of mining and the location of certain types of production.

The countries of the "Arctic Five" (Russia, the United States, Canada, Denmark, Norway) have fundamental documents (strategies) in which they determine the priorities and main directions of their activities in the Arctic. It is important to note that some countries (Finland, Sweden, Russia) in the strategic documents emphasize the provision of high-quality living conditions for the population of the Arctic zone, as well as the protection of their interests. One of the most important interests of the population of the Arctic regions is to achieve high-quality food security $[11,9,10]$. For example, in the Russian Federation, ensuring food security is one of the priority goals for the development 
of the Arctic zone of the Russian Federation and ensuring national security for the period up to 2035 [12].

Currently, the interpretation of the concept of "food security" is not uniform. The analysis showed the presence of both similarities and differences in the definitions [13,14]. The main similarities are as follows:

- the object of food security is the population, the ability to meet its nutritional needs, as well as its health;

- the determining factor of security is the quantitative indicators of the availability of food in a given territory.

In the authors ' opinion, it is optimal to use the following definition of food security: this is a state of the economy in which the entire population living in a given territory is provided with the physical availability of food in certain quantities, of appropriate quality and a wide range, and the economic availability of food, which consists in the ability to purchase these products at current prices in volumes established in accordance with the recommended consumption standards.

The official definitions of physical and economic accessibility of food are presented in the Food Security Doctrine:

- " economic accessibility of food - the ability to purchase food products of proper quality at established prices, in volumes and assortment that meet the recommended rational consumption standards;

- "physical availability of food - the level of development of commodity distribution infrastructure, at which in all localities of the country it is possible for residents to purchase food products or organize food in volumes and assortment that meet the recommended rational consumption standards" [15].

\section{Research Methods}

In Russian and foreign science, there is no single methodology for assessing the food security of regions, in particular, the regions of the Arctic zone [16,17]. The authors studied the most well-known available methods: the system of indicators included in the" Food Security Doctrine of the Russian Federation " [11], the methodology of the Food and Agriculture Organization of the United Nations [18], the methodology of the CIS Statistical Committee [19], as well as the methods of individual scientists, such as E. I. Antamoshkina [20,21].

These methods have a number of advantages. When assessing the food security of the Arctic zone of the Russian Federation, in our opinion, it is important to take into account the population size and the dynamics of its changes, which is reflected in the methodology of E. I. Antamoshkina [20, 21] and the CIS Statistical Committee [19].

However, the analysis of the methods revealed "weaknesses". Thus, in all systems of indicators for assessing food security (with the exception of the Food Security Doctrine), there is a lack of threshold values that allow us to give a clear description of the level of food security in a specific period of time.

At the same time, in the Food Security Doctrine, some of the conclusions are based only on the dynamics of indicators; there are also indicators that do not need to be evaluated in themselves. For example, rational consumption norms are fixed at the state level, and when assessing the food security of a particular region, it is not the norm itself that matters, but the compliance of regional indicators with it [18].

When analyzing the methodology of the CIS Statistical Committee, a number of nuances were also identified, in which the possibility of using the methodology for assessing food security is excluded: the presence of indicators included in the food independence, which does not relate to food security (for example, the volume of food 
imports and (or) exports, the share of own production from total consumption, the volume of domestic consumption, etc.) [19].

The main drawback of the methodology proposed by E. I. Artamoshkina is the lack of indicators that reflect the actual volume of food consumption [20, 21].

The authors of this study propose to rely on an assessment methodology consisting of 2 indicators that are designated in the Food Security Doctrine, but are not identified as indicators of food security [18]. These indicators summarize the most common indicators of the analyzed methods of Russian and foreign scientists:

$$
\begin{aligned}
& \text { economic accessibility }=\frac{\text { actual consumption per capita }}{\text { rational consumption standards }}, \% \\
& \text { physical availability }=\frac{\text { actual availability of food productsB }}{\text { availability of product sales facilities }}, \%
\end{aligned}
$$

However, the physical availability indicator is not sufficiently informative, as it may change due to an increase (decrease) in retail space. We suggest using the formulas:

$$
\begin{aligned}
& \text { economic accessibility }=\frac{\text { actual consumption per capita }}{\text { rational consumption standards }}, \% \\
& \text { physical availability }=\frac{\text { volume of foodstuffs produced }}{\text { rational consumption standards } * \text { number of population }}, \%
\end{aligned}
$$

This method allows us to take into account the small population of the Arctic zone of the Russian Federation, which means that it better reflects the specifics of the analyzed territories $[19,20]$.

\section{Results and Discussion}

To assess the state of food security in the regions of the Arctic zone of the Russian Federation, we rely on the previously proposed methodology consisting of two indicators.

Indicator 1: Physical availability of food. The physical availability of food at the expense of its own production, that is, the ability of residents to purchase food products in volumes and assortment that meet the recommended rational consumption standards, for the regions of the Arctic zone of the Russian Federation is extremely low. The threshold

\begin{tabular}{|c|c|c|c|c|c|c|c|c|c|}
\hline & 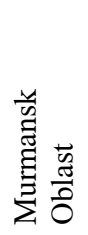 & 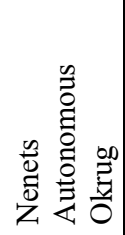 & 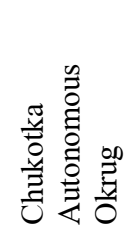 & 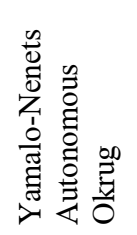 & 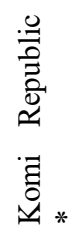 & 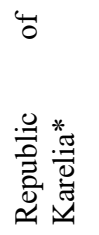 & 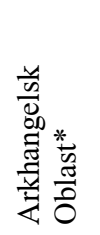 & 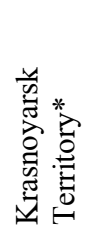 & 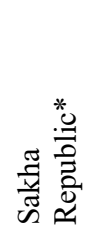 \\
\hline 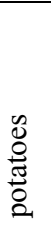 & $7 \%$ & $18 \%$ & $2 \%$ & $0,002 \%$ & $20 \%$ & $0,33 \%$ & $0,00 \%$ & $0,19 \%$ & $5,90 \%$ \\
\hline
\end{tabular}
value of $100 \%$, approved by the Food Security Doctrine, is not reached (Table 1) [18].

Table 1. Indicators of physical availability of food in the regions of the Arctic zone of the Russian Federation, 2019, \% 
Table 1. Continued

\begin{tabular}{|c|c|c|c|c|c|c|c|c|c|}
\hline 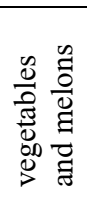 & $0,50 \%$ & $0,002 \%$ & $4 \%$ & $0,0001 \%$ & $0,80 \%$ & $0,05 \%$ & $0,00 \%$ & $0,003 \%$ & $2,50 \%$ \\
\hline 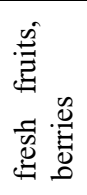 & - & - & - & - & $0,70 \%$ & - & - & - & $0,10 \%$ \\
\hline 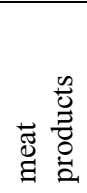 & $2 \%$ & $44 \%$ & $15 \%$ & $17 \%$ & $1,50 \%$ & $3,70 \%$ & - & - & $37 \%$ \\
\hline $\begin{array}{l}\infty \\
\infty \\
0 \\
0 \\
0\end{array}$ & $2 \%$ & - & $0,02 \%$ & - & $0,04 \%$ & $5 \%$ & - & - & $1,80 \%$ \\
\hline 柌 & $7 \%$ & $24 \%$ & $0,21 \%$ & $1,10 \%$ & $0,80 \%$ & $2 \%$ & $0,15 \%$ & - & $21,30 \%$ \\
\hline 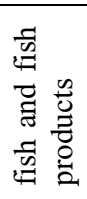 & $405 \%$ & $507 \%$ & $276,2 \%$ & $72,5 \%$ & $36 \%$ & - & - & $57 \%$ & $52,8 \%$ \\
\hline
\end{tabular}

The indicator of physical availability of food depends on the volume of agricultural production and the population of the region. For a more in-depth analysis of food security, it is important to compare actual consumption with the rational consumption norms established in the territory of the Russian Federation (Table 2) [22,11]. This comparison allows us to conclude that the population does not consume enough food [23], which is associated with both an insufficient range of products [24] and a decrease in consumption volumes. The only indicator whose threshold values were not lower than the limit values was the consumption of meat products. In our opinion, this is due to the presence of conditions for the development of some types of animal husbandry, primarily reindeer husbandry. For example, for the Chukotka Autonomous Okrug, the share of reindeer herding in the structure of agriculture is over 90\% [24]. However, it is impossible to predict sufficient food supply of the population of the regions with meat products due to the limitations in the development of the industry:

- the shortage of qualified personnel (the provision of employees is 94\%);

- low level of wages (the average wage in animal husbandry in the Chukotka Autonomous Okrug is $35 \%$ of the average salary in the region);

- depreciation of fixed assets (depreciation of machinery and equipment-over $80 \%$ ) [25]. 
Table 2. Actual food consumption in the regions of the Arctic zone of the Russian Federation and rational consumption rates, 2014 and 2019

\begin{tabular}{|c|c|c|c|c|c|c|c|c|c|}
\hline \multirow{3}{*}{$\begin{array}{l}\text { Product } \\
\text { name }\end{array}$} & \multirow{3}{*}{$\begin{array}{l}\text { Rate per } \\
\text { person } \\
\text { per year }\end{array}$} & \multicolumn{8}{|c|}{ Actual consumption } \\
\hline & & \multicolumn{2}{|c|}{$\begin{array}{l}\text { Murmansk } \\
\text { Oblast }\end{array}$} & \multicolumn{2}{|c|}{$\begin{array}{l}\text { Nenets } \\
\text { Autonomous } \\
\text { Okrug }\end{array}$} & \multicolumn{2}{|c|}{$\begin{array}{l}\text { Chukotka } \\
\text { Autonomous } \\
\text { Okrug }\end{array}$} & \multicolumn{2}{|c|}{$\begin{array}{l}\text { Yamalo- } \\
\text { Nenets } \\
\text { Autonomous } \\
\text { Okrug }\end{array}$} \\
\hline & & 2014 & 2019 & 2014 & 2019 & 2014 & 2019 & 2014 & 2019 \\
\hline Bread products & $96 \mathrm{Kg}$ & 103,1 & 66,2 & 80,1 & 97,1 & 108,1 & 81,0 & 100,1 & 85,4 \\
\hline Potatoes & $90 \mathrm{Kg}$ & 93,1 & 49,2 & 82,4 & 47,0 & 75,3 & 40,5 & 73,1 & $\mathbf{5 0 , 0}$ \\
\hline $\begin{array}{l}\text { Vegetables } \\
\text { and melons }\end{array}$ & $140 \mathrm{Kg}$ & 120,2 & 90,7 & 59,6 & 68,2 & 74,8 & 69,0 & 123,2 & 101,3 \\
\hline Fresh fruits & $100 \mathrm{Kg}$ & 94,1 & 87,0 & 50,3 & 58,4 & 86,5 & 51,0 & 108,3 & 104,7 \\
\hline Meat products & $73 \mathrm{Kg}$ & 118,8 & 84,9 & 89,8 & 79,2 & 112,0 & 83,8 & 117,1 & 112,6 \\
\hline Eggs & $260 \mathrm{PC}$ & 313 & 240 & 384 & 249 & 234 & 179 & 204 & 294 \\
\hline Milk & 340 & 365,6 & 278,0 & 212,6 & $\mathbf{3 3 5 , 7}$ & 290,6 & 213,0 & 331,3 & 292,4 \\
\hline
\end{tabular}

Table 3. Economic availability of food in some regions of the Arctic zone, 2019, \% of the norm

\begin{tabular}{|c|c|c|c|c|}
\hline & 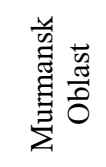 & 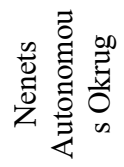 & 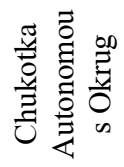 & 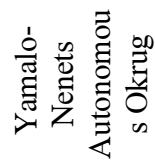 \\
\hline Bread products & $69 \%$ & $101 \%$ & $24 \%$ & $25 \%$ \\
\hline Potatoes & $55 \%$ & $52 \%$ & $12 \%$ & $15 \%$ \\
\hline Vegetables and melons & $65 \%$ & $49 \%$ & $20 \%$ & $30 \%$ \\
\hline Fresh fruits & $87 \%$ & $58 \%$ & $15 \%$ & $31 \%$ \\
\hline Meat products & $116 \%$ & $108 \%$ & $25 \%$ & $33 \%$ \\
\hline Eggs & $92 \%$ & $96 \%$ & $53 \%$ & $86 \%$ \\
\hline Milk & $82 \%$ & $99 \%$ & $63 \%$ & $86 \%$ \\
\hline
\end{tabular}

Indicator 2: Economic availability of food. Indicators of economic accessibility in the regions of the Arctic zone of the Russian Federation are presented in Table 3 (the base for analysis is limited by the availability of statistical information). They allow us to draw a conclusion about the relative economic availability of food only in two regions, the Nenets Autonomous District and the Murmansk Region (Table 3).

\section{Conclusions}

According to the results of the analysis, it can be concluded that the population of the regions of the Arctic zone of the Russian Federation is not sufficiently provided with food in terms of both physical and economic accessibility, for all types of food, with the exception of fish and fish food (fish farming), as well as deer meat (reindeer husbandry). This allows us to conclude that the achievement of the Sustainable Development Goals in these territories is rather weak and that it is necessary to strengthen the activities of the authorities in this direction.

\section{References}

1. International law, ed. A.N. Vylegzhanin (Yurayt-Publishing, 2009) 
2. National Strategy for the Arctic region, https://www.whitehouse.gov

3. The United States Navy Arctic Roadmap for 2014 to 2030, http://www.navy.mil

4. Canada's Northern Strategy, http://www.international.gc.ca

5. The Norwegian Government's Strategy for the High North), https://www.regjeringen.no

6. The High North. Visions and Strategies, https://www.regjeringen.no.

7. Strategy for the Arctic 2011-2020, https://ec.europa.eu.

8. The Northern Dimension of Canada's Foreign Policy, http://library. arcticportal.org.

9. Sweden's Strategy for the Arctic region, http://narfu.ru.

10. Finland's Strategy for the Arctic Region 2013, http://narfu.ru.

11. Decree of the President of the Russian Federation of January 21, 2020 No. 20.

12. Decree of the President of the Russian Federation of October 26, 2020 No. 645.

13. R. Capone, H. Bilali, Ph. Debs, G. Cardone, Journal of Food Security (2014)

14. G F Romashkina, et al, IOP Conf. Ser .: Mater. Sci. Eng., 940, 012122 (2020)

15. M. J. Puma, S. Bose, S. Young Chon and B.I. Cook Environ. Res. Lett., 10 (2) (2015)

16. J. Clapp, Dialogues in Human Geography, 4(2)

17. I.R. Ruiga et al 2019 IOP Conf. Ser .: Earth Environ. Sci., 315, 022073

18. FAO Food Security Indicators, http://www.fao.org

19. Interstate Statistical Committee of the CIS, http://www.cisstat.com

20. E.N. Antamoshkina, Bulletin of NSUEU, 2 (2019)

21. E. N. Antamoshkina, Scientific and technical statements of the St. Petersburg State Polytechnic University. Economic Sciences, 5 (2019)

22. Order of the Ministry of Health of Russia dated August 19, No. 614 (2016)

23. The diet of the population. 2013, Statistical Book, Rosstat-M .: IIC "Statistics of Russia" (2016)

24. Federal State Statistics Service, https://rosstat.gov.ru

25. Council of Federation of the Federal Assembly of the Russian Federation, Analytical bulletin, 44 (643) 